FILOLOGIJA 73, Zagreb 2019.

UDK 811.163.42`367.625.1

DOI https://dx.doi.org/10.21857/mjrl3ux709

Izvorni znanstveni članak

Rukopis primljen 27. V. 2019.

Prihvaćen za tisak 1. VII. 2019.

Matea Birtić

Siniša Runjaić

Odjel za opće jezikoslovlje

Institut za hrvatski jezik $\mathrm{i}$ jezikoslovlje

Republike Austrije 16, HR-10000 Zagreb

mbirtic@ihjj.hr, srunjaic@ihjj.hr

\title{
SINTAKTIČKO-SEMANTIČKA PODJELA PSIHOLOŠKIH GLAGOLA U HRVATSKOME JEZIKU
}

Tema je ovoga rada sintaktičko-semantička raspodjela hrvatskih psiholoških glagola na temelju 57 glagola koji su zastupljeni u Valencijskome rječniku psiholoških glagola u hrvatskome jeziku (tj. u mrežnoj inačici ovoga rječnika e-Glavi). Na temelju sintaktičkoga svojstva prijelaznosti glagoli se dijele $u$ tri velike skupine, a na temelju povezivanja tematske uloge iskustvenika sa sintaktičkim mjestom u strukturi, tj. s funkcijom subjekta, izravnoga objekta i neizravnoga objekta, psihološki se glagoli dalje dijele u podskupine. Unutar svake podskupine analizira se morfološki oblik iskustvenika i neiskustvenika. Izdvojeno je jedanaest podtipova psiholoških glagola na temelju dvaju spomenutih parametara. U korpusu od 57 glagola najbrojnija su skupina glagoli koji imaju povratnu i prijelaznu inačicu, a njihova prijelazna inačica pripada tipu glagola s objektnim iskustvenikom (brinuti (se), čuditi (se), ljutiti (se)). U radu se detaljno analizira njihovo sintaktičko ponašanje. Iako je podjela utemeljena na korpusu glagola iz Valencijskoga rječnika psiholoških glagola u hrvatskome jeziku i u radu se obrađuju uglavnom glagoli iz toga rječnika, na kraju se rada donosi popis svih psiholoških glagola s dativnim i objektnim iskustvenikom u hrvatskome jeziku koje su autori do sada prikupili. 
Matea Birtić, Siniša Runjaić: Sintaktičko-semantička podjela psiholoških glagola...

FILOLOGIJA 73(2019), 1-25

\section{Uvod}

U posljednjih tridesetak godina psihološki glagoli čest su predmet istraživanja u svjetskoj jezikoslovnoj literaturi (Belletti-Rizzi 1988; Grimshaw 1990; Croft 1993; Pesetsky 1995; Arad 1998; Landau 2010; Grafmiller 2013; Alexiadou-Iordăchioaia 2014). U hrvatskoj jezikoslovnoj literaturi posvećeno im je samo nekoliko radova (Belaj-Tanacković Faletar 2011; Šaravanja 2011; Brač-Matas Ivanković 2016; Oraić Rabušić 2016) te jedan valencijski rječnik (Birtić i dr. 2018). Psihološki se glagoli u hrvatskim gramatikama i priručnicima najčešće nazivaju glagolima osjećanja, glagolima duševnoga stanja i glagolima htijenja (npr. Barić i dr. 1997:518-520) ili samo glagolima osjećanja (Silić-Pranjković 2005:330, 333, 357; Težak-Babić 2005:262) te se njihove podskupine nazivaju glagolima bojazni, strahovanja i zebnje (Raguž 1997:422) ili glagolima za izražavanje emocija (Belaj-Tanacković Faletar 2011).

Velik interes za proučavanje psiholoških glagola potaknut je njihovim osobitim odnosom semantičke sa sintaktičkom strukturom. Naime, primijećeno je da kod psiholoških glagola u mnogim jezicima ista tematska uloga može biti iskazana ili izrečena na različite sintaktičke načine, tj. iskustvenik ${ }^{1}$ (onaj koji što doživljava, osjeća ili iskusi) može u mnogim jezicima, uključujući i hrvatski, biti izrečen kao subjekt u nominativu (1), objekt $u$ akuzativu (2) ili imenica $u$ dativu (3). U primjerima (1-3) navedeni su poznati talijanski primjeri iz Belletti-Rizzi (1988:291-292) te njihovi hrvatski ekvivalenti.

1. a. Gianni teme questo.

b. Ivan se boji toga.

2. a. Questo preocuppa Gianni.

b. To brine Ivana.

3. a. A Gianni piace questo.

b. Ivanu se to sviđa.

Zato se s obzirom na izricanje iskustvenika psihološki glagoli dijele u tri skupine: 1. psihološki glagoli sa subjektnim iskustvenikom (engl. Subject Experiencer Verbs, SubjExp), 2. psihološki glagoli s objektnim iskustvenikom (Object Experiencer Verbs, ObjExp) i 3. glagoli s dativnim iskustvenikom (Dative Experiencer Verbs, DExp). Tri skupine psiholoških glagola na-

1 U našoj se jezikoslovnoj literaturi rabe nazivi doživljavač (Belaj-Tanacković Faletar 2017), doživljač (Kuna 2012) i iskustvenik (Brač 2018) za tematsku ulogu koja se naziva experiencer u engleskome jeziku. Budući da su se autori ovoga rada već služili nazivom iskustvenik u svojim radovima, ostat će se pri tome nazivu. 
Matea Birtić, Siniša Runjaić: Sintaktičko-semantička podjela psiholoških glagola...

FILOLOGIJA 73(2019), 1-25

zivaju se u literaturi često i prema njihovim karakterističnim predstavnicima u talijanskome i engleskome jeziku - glagoli sa subjektnim iskustvenikom nazivaju se glagolima temere ili glagolima fear (tal. 'plašiti se, bojati se', engl. 'plašiti se, bojati se'), a glagoli s objektnim iskustvenikom nazivaju se glagolima preoccupare ili frighten (tal. 'brinuti (se)' ili engl. 'plašiti'), dok se glagoli s dativnim iskustvenikom nazivaju glagoli piacere ili appeal to (tal., engl. 'sviđati se') (Belletti-Rizzi 1988; Grimshaw 1990; Landau 2010). Katkad ih se naziva samo skupinama I, II i III (Class I, Class II, Class III, Landau 2010). U hrvatskome bi se skupine mogle nazvati i prema padežu iskustvenika, pa bismo onda razlikovali glagole s nominativnim iskustvenikom, glagole s akuzativnim iskustvenikom i glagole s dativnim iskustvenikom. Saravanja (2011) dijeli psihološke glagole u hrvatskome samo u dvije skupine: prvu skupinu naziva psihološkim glagolima doživljavanja (PGD), a drugu skupinu psihološkim glagolima uzrokovanja (PGU). U ovome ćemo ih radu zvati psihološkim glagolima sa subjektnim iskustvenikom, psihološkim glagolima s objektnim iskustvenikom i psihološkim glagolima s dativnim iskustvenikom da bi terminološki bili u skladu sa svjetskim, već ustaljenim nazivima (premda je naziv glagoli s objektnim iskustvenikom relativno neprecizan). ${ }^{2}$

\section{Tematske uloge uz psihološke glagole}

U semantičkoj strukturi psiholoških glagola uvijek nalazimo osobu ili živo biće koje nešto osjeća ili doživljava (Ivan se boji., Kuja trpi velike bolove.), a vrlo često i drugoga sudionika radnje/stanja koji ovisno o glagolu može biti uzrok (Mama me brine.), predmet kakva emotivnoga ili psihološkoga stanja (Radujem se praznicima.) ili čak sama emocija (Osjećam žalost.). Tematska uloga prvoga sudionika nedvojbena je za sve autore koji se bave psihološkim glagolima, a to je tematska uloga koja se u hrvatskome naziva doživljavačem ili iskustvenikom. Međutim, oko tematske uloge drugoga sudionika mišljenja su podijeljena. Belletti-Rizzi (1998) smatraju da uz sve tri skupine psiholoških glagola sudionici imaju iste tematske uloge: iskustvenika i temu, što je ilustrirano u primjerima od 4 do 6 .

4. Ivan se boji pasa. (iskustvenik - tema)

5. Pas plaši Ivana. (tema - iskustvenik) ${ }^{3}$

2 Taj se naziv odnosi na iskustvenike koji su izraženi izravnim objektom, a ne svim objektima. Dativni iskustvenici također se najčešće smatraju neizravnim objektima u hrvatskome.

3 Jedan od recenzenata upozorava da je u 5. primjeru dodjeljivanje tematske uloge teme imenici pas vrlo problematično. Primjeri ilustriraju opis psiholoških glagola iz Belletti-Rizzi (1998), i prema njihovu mišljenju psihološki glagoli, bez obzira na 
Matea Birtić, Siniša Runjaić: Sintaktičko-semantička podjela psiholoških glagola...

FILOLOGIJA 73(2019), 1-25

6. Ivanu se sviđa pas. (iskustvenik - tema)

U nabrojenim rečenicama Ivan je uvijek iskustvenik, a pas je uvijek tema. Mogućnost da se iste tematske uloge ostvaruju na različitim sintaktičkim mjestima predstavlja problem za većinu generativnih sintaktičkih teorija koje sukladno Bakerovoj Pretpostavci o jedinstvenosti dodjeljivanja tematskih uloga ${ }^{4}$ (Baker 1988) pretpostavljaju da se imenice s istim tematskim ulogama uvijek izvorno spajaju na iste sintaktičke položaje.

Nasuprot tomu dio autora smatra da drugi sudionik radnje/stanja kod psiholoških glagola sa subjektnim iskustvenikom, objektnim iskustvenikom i dativnim iskustvenikom nema istu tematsku ulogu. Pesetsky (1995) smatra da uz glagole sa subjektnim iskustvenikom akuzativna imenica (objekt) ima tematsku ulogu cilja emocije ili predmeta emocije, ${ }^{5}$ dok uz glagole s objektnim iskustvenikom nominativna imenica (subjekt) ima tematsku ulogu uzročnika. Primjeri pod 7 i 8 ilustriraju te tematske uloge.

7. a. Bill was angry at the article in the Times. (cilj)

Bill se naljutio / je bio ljut na članak u Timesu.

b. The article in the Times angered/enraged Bill. (uzročnik)

Članak u Timesu naljutio je Billa.

8. a. John worried about the television set. (predmet)

Ivan se brinuo za televizor.

b. The television set worried John. (uzročnik)

Televizor je brinuo Ivana.

Stoga prema njegovu mišljenju imenske skupine the article in the Times 'članak u Timesu' i the television set 'televizor' u primjerima 7 i 8 nemaju istu tematsku ulogu, nego je riječ o dvjema različitim tematskim uloga-

svoju sintaktičku strukturu, uvijek imaju argumente s istim tematskim ulogama. Primjeri ne ilustriraju mišljenje autora ovoga rada. Slažemo se s primjedbom recenzenta da pas u rečenici Pas plaši Ivana. nije tema te da postoje dvije interpretacije te rečenice, jedna u kojoj pas nenamjerno plaši Ivana i druga u kojoj on to može činiti namjerno. Tematska uloga bi tada, u skladu s analizom u Van Valin-LaPolla (1997), na koju nas je uputio recenzent rada, bila uloga efektora, a u drugoj bi interpretaciji pas mogao biti i agens. Također je napomenuto da se pas nalazi na agentivnoj strani lanca. Dvostruka interpretacija te i sličnih rečenica potvrđuje misao iz Van Valina-LaPolle (1997) da je agentivnost često posljedica načina uporabe glagola, a ne inherentno leksičko svojstvo glagola (Van Valin-LaPolla 1997:119). Sličnu ideju kasnije izlažemo na temelju Pesetskyjeva rada (Pesetsky 1995) prema čijemu opisu pas u toj rečenici ima tematsku ulogu uzročnika.

4 Uniformity of Theta Assignement Hypothesis (UTAH), Baker (1988:46).

5 Također napominje da se te dvije uloge katkada zajedničkim imenom nazivaju i objekt emocije (Pesetsky 1996:55). 
ma. U primjerima a. članak $u$ Timesu i televizor imaju ulogu cilja i predmeta emocije, dok su u primjerima b. iste imenske skupine uzročnici. Razlika između argumenta s tematskom ulogom uzročnika i onoga s tematskom ulogom cilja jest $u$ tome što je uzročnik samo uzročno vezan uz emociju koju izriče predikat, dok argument s tematskom ulogom cilja iskustvenik negativno ili pozitivno procjenjuje. Tako Pesetsky (1995) kaže da je u rečenici Bill se naljutio na članak $u$ Timesu. Bill negativno procijenio članak u Timesu i ljut je na njega, dok je u rečenici Članak u Timesu naljutio je Billa. članak u Timesu samo uzrok Billove ljutnje. U toj je rečenici moguća interpretacija prema kojoj Bill smatra da je članak u Timesu dobro napisan, ali je u njemu iznesena neka činjenica (primjerice korumpiranost vlade) koja izaziva ljutnju u Billu. Slična je situacija i s parovima rečenica s predmetom emocije i uzročnikom (8. a. i b.), gdje je uzročnik samo poticaj nekoj emociji, a zapravo nije njezin predmet, dok je u rečenicama sa subjektnim iskustvenikom akuzativni objekt uvijek predmet emocije.

Osim toga Pesetsky (1995) pretpostavlja i tematsku hijerarhiju (uzročnik > iskustvenik > cilj/predmet) prema kojoj se odvija preslikavanje argumenta na mjesta u strukturi, pri čemu je uzročnik najviši na hijerarhijskoj ljestvici. Ako u rečenici postoji uzročnik, on će se preslikati na najviše mjesto u sintaktičkoj strukturi, tj. na subjektno mjesto.

Za Pesetskoga (1995) drugi argument (neiskustvenik) uz glagol brinuti se ima tematsku ulogu predmeta emocije, dok drugi argument glagola ljutiti se (neiskustvenik) ima tematsku ulogu cilja. Nije uvijek jasno kako odrediti što je cilj, a što predmet emocije, pa će se drugi argument uz glagole sa subjektnim iskustvenikom nazivati zajedničkim imenom predmet/ cilj. To čine i mnogi drugi autori ističući prije svega važnost razlikovanja tematske uloge subjektnoga argumenta uz glagole s objektnim iskustvenikom od tematske uloge drugoga sudionika uz glagole sa subjektnim iskustvenikom (predmet/cilj prema uzročnik). Prema takvu pristupu velika skupina psiholoških glagola koji u hrvatskome mogu imati i povratnu i prijelaznu inačicu zapravo nemaju iste tematske uloge:

9. a. Brinem se za majku. (predmet emocije)

b. Ljutim se na majku. (cilj emocije)

c. Čudim se njihovoj poslušnosti. (predmet emocije)

10. a. Majka me brine. (uzročnik)

b. Majka me ljuti. (uzročnik)

c. Čudi me njihova poslušnost. (uzročnik) ${ }^{6}$

6 Ovo su konstruirani primjeri. Svi primjeri u ovome radu, osim ako nije nazna- 
Matea Birtić, Siniša Runjaić: Sintaktičko-semantička podjela psiholoških glagola...

FILOLOGIJA 73(2019), 1-25

Pripisivanje tematske uloge uzročnika nominativnomu argumentu psiholoških glagola s objektnim iskustvenikom u skladu je s razmjerno prihvaćenim mišljenjem da su glagoli s objektnim iskustvenikom (ili barem dio njih) ${ }^{7}$ uzročni (Croft 1993; Grimshaw 1990; Pesetsky 1995). Croft (1993) ne raspravlja eksplicitno o tematskim ulogama argumenata uz psihološke glagole, ali naziva drugu ulogu uz glagole s objektnim iskustvenikom poticajem (stimulus). Levin (1993) također tvrdi da psihološki glagoli imaju dva argumenta: iskustvenik i poticaj (stimulus). S obzirom na to kako izražavaju ta dva argumenta, Levin (1993) psihološke glagole dijeli u četiri skupine (pretežito u engleskome jeziku): dvije skupine prijelaznih i dvije skupine neprijelaznih glagola. Dvije skupine prijelaznih glagola razlikuju se s obzirom na to je li im iskustvenik subjekt (the admire verbs) ili objekt (the amuse verbs), a skupina neprijelaznih glagola s obzirom na to je li iskustvenik subjekt (the marvel verbs) ili se nalazi unutar prijedložne skupine (the appeal verbs).

Brač (2018) u svojoj knjizi posvećenoj instrumentalu analizira psihološke glagole koji uza sebe imaju dopunu u instrumentalu i smatra da je takav instrumental uzročnik emocije. Također spominje rečenične parove (Ne trebate se zaludivati mitovima. - Ne trebaju vas zaludivati mitovi.) u kojima su mitovi u oba slučaja uzročnici (Brač 2018:192-198). Dakle, autorica ne smatra da su tematske uloge neiskustvenika kod psiholoških glagola sa subjektnim i objektnim iskustvenikom različite. Autorica promatra samo one neiskustvenike koji se mogu izreći instrumentalom te njihova značenja promatra kroz prizmu svih instrumentalnih značenja u jeziku. ${ }^{8}$

\section{Podjela glagola s obzirom na prijelaznost}

Što se tiče podjele glagola s obzirom na svojstvo prijelaznosti, ${ }^{9}$ psiho-

čeno da su iz kojega lingvističkog djela ili su ih konstruirali autori, potječu iz Valencijskoga rječnika psiholoških glagola u hrvatskome jeziku.

7 Kasnije su autori utvrdili da psihološki glagoli s objektnim iskustvenikom nemaju samo jednu interpretaciju. Arad (1998) čak razlikuje tri interpretacije kod psiholoških glagola s objektnim iskustvenikom (agentivna, događajna (neagentivna) i stativna).

8 Treba napomenuti da ista autorica u radu Психологические глаголь в хорватском и русском языках (2016), napisanome u suautorstvu s Ivanom Matas Ivanković, zapravo razlikuje tematske uloge predmeta/cilja emocije i uzročnika na isti način kao što se to čini i u ovome radu.

9 U lingvističkoj literaturi unutar različitih jezikoslovnih smjerova svojstvo glagola da uza sebe ima određeni broj leksičkih jedinica (imenica, prijedložnih skupina ili pridjeva) naziva se valentnost glagola ili njegova argumentna struktura (Samardžija 1986; Birtić 2008). Svojstvo glagola da uza sebe traži ili ne traži objekt obično se na- 
loški glagoli u hrvatskome mogu biti prijelazni (11), neprijelazni (12) i povratni (13):

11. Petar voli Tenu.

12. Marija trpi (od bolova).

13. Divim se njegovoj odvažnosti.

Mnogi psihološki glagoli mogu biti u isto vrijeme prijelazni i povratni ili neprijelazni i povratni te čak prijelazni, neprijelazni i povratni, o čemu će biti riječi kasnije.

\section{3. a. Neprijelazni glagoli}

Samo neprijelazni glagoli

U popisu od 57 psiholoških glagola sedam je glagola samo neprijelazno, tj. nemaju odgovarajuću povratnu ili prijelaznu inačicu. To su sljedeći glagoli: dosaditi, faliti, nedostajati, poludjeti, reagirati, tugovati i zavidjeti. Unutar ove skupine možemo razlikovati dvije podskupine. Prvu podskupinu (a) tvore glagoli koji izražavaju iskustvenika nominativom (poludjeti, reagirati, tugovati, zavidjeti), a drugu podskupinu (b) glagoli kojima je iskustvenik u dativu (dosaditi, faliti, nedostajati).

14. Porotnici ne tuguju za svojom bivšom pozicijom. (nominativni iskustvenik)

15. Blanki je dosadila duga kosa. (dativni iskustvenik)

U prvoj skupini glagoli poludjeti i tugovati mogu izražavati predmet/cilj emocije prijedložnim izrazom sa $z a$ i instrumentalom. Osim toga glagol poludjeti u svojemu temeljnom značenju 'postati lud ili umobolan' ne treba nikakvu dopunu (Totalno je poludio i morali su ga odvesti u Jankomir.), dok u značenjima postati ljutit na koga ili što, postati pretjerano zanesen čime i pretjerati s čime može imati prijedložne dopune na s akuzativom te $z a$ ili $s(a) \mathrm{s}$ instrumentalom (Poludjela je na žiri zbog njihovih komentara., Svi su poludjeli za ovim vozilom., Poludjeli su s tim bacanjem petardi.). Uz glagol zavidjeti osim nominativnoga iskustvenika nalazimo onoga komu zavidimo u dativu, a ono na čemu zavidimo u prijedložnome izrazu na i lokativ (Zavidim bratu na kući.). Barić i dr. (1997) navode da glagol zavidjeti otvara mjesto dvama objektima, dativnome i prijedložnome u lokativu (Barić i dr. 1997:444).

ziva njegovom rekcijom, prema kojoj je glagol prijelazan ili neprijelazan (Barić i dr. 1997:230). Pod svojstvom prijelaznosti u ovome radu podrazumijevamo mogućnost glagola da bude prijelazan, neprijelazan i povratan. Dakle, opseg je toga svojstva širi od rekcije i uključuje i povratne glagole, ali je uži od njegove valentnosti i argumentne strukture, koje uključuju i subjekt. Na sličan je način prijelaznost definirana i u Barić i dr. (2007) i Silić-Pranjković (2005) (predikatna kategorija prijelaznosti). 
Matea Birtić, Siniša Runjaić: Sintaktičko-semantička podjela psiholoških glagola...

FILOLOGIJA 73(2019), 1-25

Ako prihvatimo takvu analizu, oba su izraza argumenti glagola zavidjeti te bi trebali imati tematske uloge. Međutim, teško je odgovoriti na pitanje kako na odgovarajući način odrediti njihove tematske uloge. Postoje dva osnovna smjera razmatranja tematskih uloga imenskih skupina bratu i kući uz glagol zavidjeti. Prema prvome argumenti bratu i kući posve su odvojeni argumenti sa zasebnim tematskim ulogama. Prema Pesetskyjevoj analizi, koju primjenjujemo u ovome radu, drugi argument glagola zavidjeti (glagol sa subjektnim iskustvenikom) ima ulogu predmeta ili cilja emocije. Međutim, tu imamo dva argumenta, a ne jedan te bismo mogli pomisliti da dva unutarnja argumenta ovoga glagola imaju uloge predmet/cilj (kuća) i uzročnik (brat). No, takva je tvrdnja u snažnome nesuglasju s Pesetskyjevim pristupom, prema kojemu se uzročnik (rezerviran za glagole s objektnim iskustvenikom) i predmet/cilj emocije (drugi argument glagola sa subjektnim iskustvenikom) ne mogu pojaviti uz isti predikat, tzv. ograničenje TS/M (Target/Subject Matter Restriction). ${ }^{10}$ Slično tvrde i Van Valin-LaPolla (1997:126). ${ }^{11}$ Međutim, supojavljivanje predmeta i cilja emocije $\mathrm{u}$ istoj rečenici, prema Pesetskome, nije isključeno, npr. u rečenici Sue is angry with Bill about the party. 'Sue je ljuta na Billa zbog / radi / u vezi proslave' vidimo da se uz predikat angry 'ljut' pojavljuju i cilj i predmet emocije (Bill i party). Smatramo da bi slična analiza bila primjenjiva i na glagol zavidjeti:

16. Zavidim bratu (cilj emocije) na kući (predmet emocije).

10 Pesetsky (1996) uvodi tzv. The Target/Subject Matter Restriction te kaže „Cause and Target/Subject Matter argument cannot occur with the same predicate « i svoje pravilo potkrepljuje primjerima kao što je *The article in the Times angered Bill at the government. 'Clanak u Timesu naljutio je Bila na vladu', koji se ni u hrvatskome ne čini gramatičnim.

11 Jedan od recenzenata ovoga rada ponovno nas je uputio na Van Valina-LaPollu (1997) koji donose detaljnu razradu tematskih uloga dvomjesnih stativnih predikata. U engleskome primjeru, koji bi bio najsličniji našemu primjeru s glagolom zavidjeti (Charles hates his wife. 'Charles mrzi svoju ženu'), izdvajaju dvije specifične tematske uloge (emoter i target 'cilj'). Kod drugih stativnih glagola prisutne su druge tematske uloge, primjerice Mabel saw the accident. 'Mabel je vidjela nesreću.' (perciver 'opazitelj' i stimulus 'poticaj'). Budući da analiziraju samo dvomjesne predikate i kažu da se na prvome i drugome mjestu uz predikat određene uloge isključuju, u okvirima njihove analize ne vidimo rješenje našega problema (»There are two groups of thematic relations here, the first arguments and the second arguments of the state predicates, and a crucial fact about these two groups is that the members of each group do not contrast with each other. That is, no single predicate takes more than one argument from the group... [THEME, ENTITY, STIMULUS, CONTENT, DESIRE, JUDGEMENT, CREATION, LOCUS, IMPLEMENT]...« (Van Valin-LaPolla 1997:126)). S druge strane, poslije će se vidjeti da mi uz glagol zavidjeti izdvajamo tematsku ulogu cilja, što oni također izdvajaju uz glagol hate 'mrziti.' 
Matea Birtić, Siniša Runjaić: Sintaktičko-semantička podjela psiholoških glagola...

FILOLOGIJA 73(2019), 1-25

Drugi je smjer razmišljanja analiza imenskih skupina brat i njegova kuća kao dijelova koji nose istu tematsku ulogu. Premda je poznato da dva argumenta uz isti predikat ne mogu imati istu tematsku ulogu, ${ }^{12}$ postoje autori koji su uočili da se katkad isti argument može ostvariti na više različitih sintaktičkih načina. Levin (1993:73) među ostalim izdvaja i glagole čiji se argumenti mogu ostvariti kao jedna posvojna imenska skupina ili kao dva odvojena dijela od kojih je jedan besprijedložni, a drugi prijedložni izraz. Glagole takvoga tipa Levin svrstava u one koji pokazuju tzv. Possessor-Attribute Factoring Alternation ${ }^{13}$ koja pripada alternacijama argumenata unutar VP-a. ${ }^{14}$ Glagol envy, koji se može smatrati ekvivalentom hrvatskomu zavidjeti, pripada glagolima koji pokazuju tu vrstu smjene (Levin 1993):

17. a. I envy him for his car. 'Zavidim mu na autu.'

b. I envy his car. 'Zavidim na njegovu autu.'

Korpusna je pretraga potvrdila da se u hrvatskome jeziku glagol zavidjeti često pojavljuje samo s dativom ili s dativom i prijedložnim lokativom (Zavidim bratu. / Zavidim bratu na kući.). Dativna imenska skupina odnosi se gotovo uvijek na živi referent, a samo iznimno na neživi, u prenesenome značenju (Ivan zavidi moru koje je prima u svoje naručje.).

Primjeri u kojima glagol zavidjeti ima samo prijedložnu dopunu vrlo su rijetki (Mogu ljudi zavidjeti na vašoj sreći. ${ }^{15}$ ). Pretragom korpusa može se utvrditi da je u onim pojavnicama u kojima je glagol zavidjeti bez dativa imenica uklopljena u prijedložni izraz najčešće dodatno određena posvojnim (često), opisnim pridjevom (rijetko) ili kojom dodatnom dopunom:

12 Dodjeljivanje iste tematske uloge dvama rečeničnim dijelovima također je teorijski upitno. Postoji tzv. načelo tematske raznolikosti (»If $\alpha$ and $ß$ are distinct arguments of a predicate $\mathrm{P}$, the thematic role assigned to $\alpha$ must be be distinct from the thematic role assigned to ß « Pesetsky (1996:62). 'Ako su $\alpha$ i $ß$ različiti argumenti predikata P, tematska uloga dodijeljena argumentu $\alpha$ mora biti različita od tematske uloge dodijeljene argumentu $\left.\Omega^{\prime}\right)$. Međutim, također je zamijećeno da postoje sintaktičke situacije u kojima je veoma teško održati tematsku raznolikost dvaju argumenata, pogotovo kod tzv. simetričnih predikata (Marko i Ana se vole.).

13 Takva smjena nastaje jer posvojnik (posjednik) i posjedovani atribut mogu biti ostvareni na dva različita načina (kao jedan argument ili kao dva). Ako je riječ o jednome argumentu, tj. jednoj imenskoj skupini, posjedovani je atribut glava imenske skupine, a posvojnik je, u engleskome jeziku, genitivni atribut. Ako su ostvareni posebno, jedan je od njih subjekt ili objekt, a drugi se ostvaruje s pomoću prijedložne skupine. Glagol envy 'zavidjeti' pripada podvrsti u kojoj alternira objekt.

14 Alternacijama unutar VP-a među ostalim pripadaju lokativna, dativna i alternacija posvojnosti dijela tijela, koja je najbliža gore navedenoj.

15 Primjer iz Hrvatskoga mrežnog korpusa (hrWaC). 
Matea Birtić, Siniša Runjaić: Sintaktičko-semantička podjela psiholoških glagola...

FILOLOGIJA 73(2019), 1-25

18. Mogu ljudi zavidjeti na vašoj sreći.

19. Zavidim na njegovu talentu lakog podnošenja života.

Ako je prisutan dativni cilj zavisti, imenica unutar prijedložne lokativne skupine ne mora biti dodatno specificirana (Zavidim bratu na kući.). Međutim, primjeri bez dodatne odredbe imenice unutar prijedložnog izraza i bez dativnog argumenta nisu sasvim uobičajeni (?Djevojka zavidi na kući.). Budući da je uz imenicu unutar prijedložnoga izraza najčešći posvojni pridjev, možemo zaključiti da je (živi) cilj zavisti uvijek prisutan, implicitno ili eksplicitno. Eksplicitno se izriče dativom ili posvojnim pridjevom, ali može biti implicitno prisutan u kontekstu. Na kraju je možda potrebno spojiti oba navedena smjera razmišljanja i zaključiti da glagol zavidjeti uvijek ima obveznu dopunu s ulogom cilja (dativ) i neobveznu dopunu s ulogom predmeta koji na neki način pripada cilju (prijedložni izraz s na), a u nekim se slučajevima cilj i predmet izriču zajedno. Izricanje samoga predmeta bez cilja nije posve uobičajeno.

Glagol reagirati u psihološkome značenju može biti popraćen prilogom (reagiratibijesno) ili prilogom i prijedložnim izrazom na s akuzativom (bijesno reagirati na najnoviji čin islamista), dakle cilj/predmet emocije izražen je uz ovaj glagol prijedložnim izrazom s na. Glagole dosaditi, faliti i nedostajati povezuje to što iskustvenike izražavaju dativom, s tim da su glagoli faliti i nedostajati temeljno egzistencijski glagoli, a samo im je jedno značenje psihološko. Zanimljivo je da se glagol dosaditi svojstvom prijelaznosti/povratnosti razlikuje od svojega vidskog parnjaka dosađivati koji može uz prijelaznu imati i povratnu inačicu (dosađivati se), dok dosaditi ne može. To je jedini psihološki glagol u našemu korpusu koji se razlikuje prema svojstvu prijelaznosti od svojega vidskog parnjaka. Predmet emocije ${ }^{16}$ kod glagola dosaditi, dosađivati, faliti i nedostajati izražen je nominativom (Blanki je dosadila duga kosa., Fali mi mama.). Kod glagola nedostajati i faliti predmet emocije može biti i u genitivu (Ljudima nedostaje ljubavi.). Riječ je o dijelnome genitivu koji može zamijeniti nominativ ili akuzativ, ovisno o tipu glagola. Stoga su ta četiri glagola predstavnici treće skupine psiholoških glagola, onih s dativnim iskustvenikom. Inače istomu semantičko-sintaktičkom tipu nepovratnih glagola s dativnim iskustvenikom i nominativnim predmetom emocije pripada nevelik broj glagola $u$ hrvatskome jezi-

16 Pesetsky (1996) razlikuje tematske uloge neiskustvenika koje se javljaju s glagolima please 'ugoditi, goditi, svidjeti se' i appeal to 'svidjeti se.' Uz please subjektni argument je uzročnik, a uz appeal to predmet/cilj emocije. Stoga kaže da glagolima piacere odgovara zapravo appeal to, a ne please. Stoga i mi analogijom smatramo da glagoli s dativnim iskustvenikom kao drugi argument imaju predmet/cilj emocije. 
ku, a to su još i glagoli dojaditi, dodijati, dozlogrditi, goditi i prisjesti. ${ }^{17}$ Dativni iskustvenik imaju povratni glagoli i neke konstrukcije s psihološkim pridjevima (Žao mi ga je.). Popis svih glagola s dativnim iskustvenikom dosad pronađenih u hrvatskome jeziku nalazi se na kraju ovoga članka.

\section{3. b. Povratni glagoli}

Samo povratni glagoli

Jedanaest glagola iz Valencijskoga rječnika psiholoških glagola u hrvatskome jeziku pripadaju tzv. glagolima reflexiva tantum, tj. onima koji imaju samo povratnu inačicu (bojati se, nadati se, ponositi se, sjećati se, sramiti se, stidjeti se, svidjeti se, svidati se, usuditi se, usudivati se, zaljubiti se). I ova se skupina glagola opet dijeli s obzirom na to je li im iskustvenik izrečen nominativom ili dativom. Kod devet glagola iskustvenik je izrečen nominativom (20), a kod samo dva dativom (svidjeti se i svidati se, 21):

20. Bojim se aviona. (nominativni iskustvenik)

21. Sviđa mi se ta haljina. (dativni iskustvenik)

U prvoj podskupini glagole dijelimo na one čiji je drugi sudionik (predmet/cilj emocije) izražen genitivom (bojati se aviona, sjećati se majke, sramiti se ljudi i stidjeti se suza), dativom (nadati se uspjehu), instrumentalom (ponositi se sinom) ili prijedložnom skupinom (zaljubiti se u djevojku). Glagol zaljubiti se također može imati uzajamnopovratno značenje i u tome slučaju druga dopuna izostaje. Glagoli usuditi se i usudivati se vrsta su modalnih glagola, pa je njihova druga dopuna uvijek infinitivna.

Glagoli svidjeti se i svidati se jedini su predstavnici skupine glagola s dativnim iskustvenikom među povratnim psihološkim glagolima u obrađivanome rječniku. Takvim glagolima u hrvatskome jeziku pripadaju i glagoli dopasti se, dopadati se, gnušati se, smučiti se, omiliti se, gaditi se, sažaliti se, zgaditise.

\section{Povratni i neprijelazni}

Ova skupina glagola mogla bi se svrstati i u prvu skupinu, tj. činiti podvrstu neprijelaznih glagola. Među 57 glagola iz Valencijskoga rječnika psiholoških glagola u hrvatskome jeziku samo dva mogu biti povratni i neprijelazni: dosađivati i patiti. Kod glagola patiti neprijelazna i povratna inačica imaju različito iznijansirana značenja, a iskustvenik je uvijek izražen nominativom:

17 Kao glagole raspoloženja i duševnoga stanja s dativnim objektom Katičić (2002:117) navodi i glagole sijevnuti i sinuti, koji imaju istu argumentnu strukturu (Sinula mi je nova ideja.). Međutim oni bi, prema našoj podjeli, prije pripadali glagolima mišljenja. 
Matea Birtić, Siniša Runjaić: Sintaktičko-semantička podjela psiholoških glagola...

FILOLOGIJA 73(2019), 1-25

22. Glumica je patila za glamuroznim životom i skupim vilama. (nominativni iskustvenik) ‘biti nesretan bez prisutnosti koga/čega; čeznuti'

23. Baš ručam neku piletinu i patim se s nožem i vilicom. (nominativ ni iskustvenik) 'prolaziti kroz patnju ili muku; mučiti se'

Tu svakako treba napomenuti da bi glagol patiti trebalo premjestiti u skupinu onih glagola koji mogu biti prijelazni, neprijelazni i povratni, na što nas je dobro upozorio jedan od recenzenata ovoga rada. U Hrvatskome mrežnom korpusu zabilježeni su, među ostalim, sljedeći primjeri:

24. a. Ali mnogo više patile ga duševne muke.

b. Pate me vrtoglavice i strašna glavobolja.

Budući da se podjela glagola u sintaktičke tipove u ovome radu oslanja na opis u već objavljenome Valencijskom rječniku psiholoških glagola u hrvatskome jeziku, podjelu u ovome radu ne možemo mijenjati. ${ }^{18}$

Glagol dosađivati u neprijelaznome obliku izriče iskustvenika dativom, a u povratnome nominativom. Uočljiv je paralelizam s glagolima s objektnim iskustvenikom (3. c. c.):

25. Takva mi kosa već jako dosađuje. (dativni iskustvenik)

26. Djevojka se dosađuje s takvom kosom. (nominativni iskustvenik)

3. c. Prijelazni glagoli

Kod prijelaznih glagola izdvajaju se tri podskupine:

(a) glagoli koji su samo prijelazni

(b) glagoli koji mogu biti prijelazni i neprijelazni

(c) glagoli koji mogu biti prijelazni i povratni.

Samo prijelazni glagoli

Ovoj skupini pripadaju glagoli koji imaju samo prijelaznu inačicu te nemaju istokorijenski povratni ni neprijelazni glagol. Oni su prototipni prijelazni glagoli kod kojih je iskustvenik izražen nominativom, a predmet/cilj emocije akuzativom:

18 Međutim, promjenu je moguće unijeti u e-Glavu, mrežnu inačicu spomenutoga rječnika. Glagol patiti u rječniku ima četiri značenja:

1. podnositi tjelesnu i/ili psihičku bol; osjećati se iznimno neugodno ili loše; trpjeti

2. trpjeti kakav fizički ili psihički poremećaj; bolovati od čega

3. biti pod utjecajem loših posljedica; trpjeti, stradavati

4. biti nesretan bez prisutnosti koga/čega; čeznuti.

Pretpostavljamo da bi prijelazna inačica ovoga glagola pripadala prvomu značenju. 
Matea Birtić, Siniša Runjaić: Sintaktičko-semantička podjela psiholoških glagola...

FILOLOGIJA 73(2019), 1-25

27. Marija obožava sladoled.

Unutar našega korpusa od 57 glagola toj skupini pripada osam glagola (doživjeti/doživljavati, obožavati, očekivati, podnijeti/podnositi, poštovati, željeti). Glagoli ove skupine često nemaju samo psihološko značenje nego pripadaju i drugim semantičkim skupinama glagola (usp. podnijeti/podnositi u Valencijskome rječniku psiholoških glagola u hrvatskome jeziku).

Prijelazni i neprijelazni glagoli

U Valencijskome rječniku psiholoških glagola u hrvatskome jeziku pet glagola mogu biti i prijelazni i neprijelazni. To su glagoli izdržati, trebati, trpjeti, uživati, žudjeti, npr.

28. Ja ne mogu više izdržati u samostanu.

29. Teško je izdržala tu nesreću.

Kod glagola izdržati, trpjeti, uživati i žudjeti iskustvenik je u objema inačicama u nominativu, dok je kod glagola trebati u prijelaznome obliku u nominativu, a u neprijelaznome obliku $u$ dativu:

30. Ja trebam ljubav/ljubavi. (nominativni iskustvenik)

31. Meni treba više ljubavi. (dativni iskustvenik)

Iako se glagol žudjeti može javiti i u prijelaznoj i neprijelaznoj inačici, obje inačice nemaju istu stilsku vrijednost (Dijete žudi vrući poljubac.). Glagol uživati ima dva psihološka značenja, u kojima je neprijelazan, te dva nepsihološka značenja u kojima je prijelazan; u trećemu značenju pripada glagolima posjedovanja, uzimanja i davanja, tj. mijenjanja posjednika, a u četvrtome glagolima konzumacije (Predsjednik uživa imunitet. Mladi uživaju drogu.).

Prijelazni i povratni glagoli

Najbrojnija su od svih skupina glagoli koji mogu imati i prijelaznu i povratnu inačicu. Među njima razlikuju se tri podskupine glagola s obzirom na izricanje iskustvenika. Prva su podskupina glagoli koji u prijelaznoj inačici imaju iskustvenika $\mathrm{u}$ akuzativu i uzročnika u nominativu, a odgovarajućim povratnim glagolima iskustvenik je u nominativu (čuditi - čuditi se). Druga su podskupina glagoli koji i u prijelaznoj i u povratnoj inačici imaju iskustvenika u nominativu (osjećati - osjećati se), dok su treća podskupina prijelazni glagoli čija povratna inačica ima samo uzajamnopovratno značenje (voljeti - voljeti se). 
Matea Birtić, Siniša Runjaić: Sintaktičko-semantička podjela psiholoških glagola...

FILOLOGIJA 73(2019), 1-25

Prva je podskupina najbrojnija. Njoj pripada šesnaest glagola u Valencijskome rječniku psiholoških glagola u hrvatskome jeziku (brinuti (se), čuditi (se), iznenaditi (se), koncentrirati (se) (samo je povratno značenje psihološko), ljutiti (se), naviknuti (se), plašiti (se), radovati (se), razveseliti (se), ražalostiti (se), umiriti (se), uvrijediti (se), uzrujavati (se), razveseliti (se), veseliti (se), vrijedati (se), zabavljati (se), žaliti (se), ${ }^{19}$ živcirati (se)). ${ }^{20}$

Prijelazna inačica tih glagola odgovara glagolima koje smo u uvodu nazvali glagolima s objektnim iskustvenikom (glagoli frighten ili preoccupare).

32. Političare ljute najavljeni prosvjedi sindikata. (akuzativni iskustvenik, prijelazni glagol)

33. Političari se ljute na najavljene prosvjede sindikata. (nominativni iskustvenik, povratni glagol)

U primjeru 32 prijelazni je glagol ljutiti s akuzativnim iskustvenikom (političare) i subjektnim uzročnikom (najavljeni prosvjedi sindikata). U primjeru 33 akuzativni je iskustvenik iz rečenice 32 izrečen nominativom (političari), glagol je povratan, a predmet/cilj emocije izrečen je prijedložnom skupinom s prijedlogom na. Kao što je već rečeno u uvodu, glagoli koji odgovaraju hrvatskomu primjeru pod 32, tj. glagoli s objektnim iskustvenikom izazivaju veliku pozornost u svjetskoj lingvističkoj teoriji. Posebice su se na njih osvrtale generativne teorije. U okviru tih teorija sporno je postojanje dviju srodnih konstrukcija s istim glagolima ${ }^{21}$ unutar kojih se temat-

19 Prema opisu u Valencijskome rječniku psiholoških glagola u hrvatskome jeziku glagol žaliti ima tri nepovratna i tri povratna značenja (1. osjećati žalost, često zbog čega, 2. osjećati sućut prema komu; dijeliti žalost s kime, 3. osjećati žalost za onim koga/ čega više nema, 4. povr. iskazivati neraspoloženje ili nezadovoljstvo; tužiti se, jadati se, 5. povr. iskazivati nezadovoljstvo, neraspoloženje čime, često komu, 6. povr. podnositi prigovor ili žalbu kojemu službenom tijelu). Osnovna je razlika između nepovratnih i povratnih značenja $u$ tome što je $u$ nepovratnim značenjima glagol psihološki, a kod povratnih značenja najčešće je glagol komunikacije (žaliti se najčešće uključuje neki vid verbalne radnje).

20 Jedan od recenzenata ovoga rada predložio je da u ovu skupinu uvrstimo i glagole žalostiti (se) i sažalijevati (se) koji nisu prisutni u našemu opisu jer se ne nalaze u Valencijskome rječniku psiholoških glagola u hrvatskome jeziku. Posve je jasno da glagol žalostiti pripada ovoj skupini (Tvoje me ponašanje žalosti. / Žalostim se tvojim ponašanjem.). Međutim, za glagol sažalijevati to nije tako očito (Sažalijevam tvoju ženu. / Sažalijevao se nad tvojom ženom.). Čini se da ovaj glagol u objema inačicama ima subjektnoga iskustvenika, pa bi prije pripadao glagolima prethodne podskupine (osjećati osjećati se). Moguće je da je recenzent na tu skupinu i mislio. Međutim, u svakome mu slučaju zahvaljujemo jer smo na taj način proširili popis svih glagola s objektnim iskustvenikom u hrvatskome jeziku.

21 Legitimno je pitanje treba li tu govoriti o istome glagolu. Jesu li glagoli ljutiti i ljutiti se inačice istoga glagola ili je riječ o dvama glagolima? Odgovor na to djelo- 
Matea Birtić, Siniša Runjaić: Sintaktičko-semantička podjela psiholoških glagola...

FILOLOGIJA 73(2019), 1-25

ske uloge ostvaruju na različitim sintaktičkim mjestima (primjeri 32 i 33). Već je istaknuto u drugome poglavlju da su takve konstrukcije u neskladu s Bakerovim načelom o jedinstvenosti dodjeljivanja tematskih uloga ili s Perlmutterovim i Postalovim načelom univerzalnoga redanja ${ }^{22}$ (Rozwadowska 2017). Za taj problem postoje dva rješenja. Prvo je rješenje pretpostavka da psihološki glagoli s objektnim i subjektnim iskustvenikom zapravo nemaju iste tematske uloge za neiskustvenika (Pesetsky 1996), a drugo da je riječ o konstrukcijama s istim tematskim ulogama koje su derivacijski povezane (Belletti-Rizzi 1988).

Za hrvatski je jezik karakteristično da (gotovo) svakomu psihološkom glagolu s objektnim iskustvenikom odgovara povratni glagol s nominativnim iskustvenikom. ${ }^{23}$

U Valencijskome rječniku psiholoških glagola u hrvatskome jeziku nema niti jednoga glagola koji bi pripadao glagolima s akuzativnim iskustvenikom, a da u isto vrijeme nema i povratnu inačicu. Međutim, $u$ hrvatskome se je-

mice leži i u našemu shvaćanju gramatike. Ako smatramo da je jedan glagol ili jedna inačica izvedena od druge nekim procesom (morfološkim ili sintaktičkim) u gramatici, onda ih je opravdano smatrati jednim glagolom. Međutim, ako smatramo da već u leksikonu postoje dvije leksičke jedinice (ljutiti i ljutiti se) s dvjema različitim argumentnim strukturama i različitim značenjima, onda je nedvojbeno riječ o dvama glagolima. Drugo rješenje mnogi autori smatraju nedostatnim (vidi primjerice Schäfer 2009:2).

22 Načelo Universal Alignment Hypothesis (UAH) načelo koje su predložili Postal i Perlmutter 1984. godine ovdje se prevodi kao načelo univerzalnoga redanja i citira se prema Rozwadowska (2017).

23 Svojstvo da se gotovo svaki psihološki glagol s objektnim iskustvenikom pojavljuje i u povratnoj inačici uočeno je u mnogim jezicima (slavenskim, romanskim i grčkom) te se smatra jednom od vrsta uzročne smjene (uzročnoinkoativna smjena), engl. causative alternation (Schäfer 2009; Rozwadowska 2017). U uzročnoj smjeni glagol pokazuje dva sintaktička obrasca: Maria opens the window. / The window opens. (Marija je otvorila prozor. / Prozor se otvorio.). U prvoj rečenici glagol je uzročan, a u drugoj je inkoativan ili antiuzročan. Objekt prijelazne ili uzročne varijante postaje subjekt inkoativne inačice, koju uvijek obilježava povratna čestica se u hrvatskom. Iako kod psiholoških glagola također vidimo da objekt prijelaznoga (uzročnoga) glagola postaje subjekt inkoativnoga (povratnoga) glagola, psihološki se glagoli razlikuju od tipičnih predstavnika koji sudjeluju u uzročnoj smjeni prema dvama svojstvima. Budući da je objekt temeljne prototipne prijelazne uzročne konstrukcije najčešće neživ, kao subjekt inkoativne ili antiuzročne rečenice nalazimo obično neživi objekt (Olovka se slomila., Prozor se otvorio.). Međutim, kod psiholoških glagola objekt uzročnoga glagola uvijek je živ, pa tako i subjekt inkoativnoga. Druga je osobitost psiholoških glagola da se drugi argument (subjekt temeljne rečenice) (ako je to isti argument) najčešće može izreći prijedložnim izrazom, genitivom, dativom ili instrumentalom (Avioni me plaše. / Plašim se aviona.), dok kod drugih inkoativnih ili antiuzročnih glagola drugoga argumenta nema (Olovka se slomila., Prozor se otvorio.). 
ziku općenito ipak javljaju psihološke prijelazne konstrukcije s objektnim iskustvenikom bez povratne inačice $\mathrm{u}$ istome značenju. Tada je riječ o glagolima čija značenja nisu temeljno psihološka, nego su psihološka značenja dobili u određenome kontekstu:

34. Mene boli njegova šutnja.

*Ja se bolim njegove šutnje.

35. Uoči izbora hvata ih jeziva histerija.

*Oni se hvataju jezive histerije.

36. Glazbena umjetnost pogotovo nas dira u srce.

*Ja se diram u srce glazbenom umjetnošću. ${ }^{24}$

Glagol boljeti u svojemu temeljnom značenju pripada somatskim glagolima, a glagoli hvatati i dirati glagolima kontakta i diranja. Arad (1998) naglašava da gotovo svaki glagol s neagentivnim subjektom u odgovarajućemu kontekstu može biti protumačen psihološki, pa spominje primjer glagola kill 'ubiti' u engleskome jeziku, ${ }^{25}$ što dokazuju i navedeni primjeri iz hrvatskoga. Glagole te skupine možemo podijeliti prema morfološkome obliku drugoga sudionika radnje povratnih glagola (predmet/cilj emocije). Većinom glagoli te skupine izražavaju predmet/cilj emocije u povratnoj inačici prijedložnim izrazom (brinuti, ljutiti, uvrijediti, živcirati, vrijeđati, naviknuti): Brinem se za majku., Ljutim se na igrače., Uvrijedio sam se na brata., Živciram se oko gluposti., Premijerka se vrijeđa na taj tekst., Naviknula sam se na rano buđenje. Dio njih u povratnoj inačici ima genitivnu dopunu kao drugi argument (Plašim se pasa.). Obično se tvrdi da se genitivna dopuna kod psiholoških glagola javlja kad glagol izražava kakvu negativnu emociju (Belaj - Tanacković Faletar 2011:158). U Valencijskome rječniku psiholoških glagola u hrvatskome jeziku osim glagola plašiti se, koji ima i prijelaznu inačicu, prisutna su i četiri povratna glagola (bojati se, sjećati se, sramiti se, stidjeti se) s genitivnom dopunom, od kojih tri zaista izražavaju negativnu emociju. ${ }^{26}$ Tri glagola koja imaju prijelaznu i povratnu inačicu drugoga sudionika radnje u povratnoj inačici, tj. predmet/cilj emocije izražavaju dativom (čuditi se, radovati se, veseliti se - Moj otac veselio se pobjedama mojeg $k l u b a$.). Kod glagola zabavljati se i umiriti se drugi sudionik radnje (neiskustvenik) ostvaruje se instrumentalom (Zabavljam se sviranjem., Umirujem se sviranjem.). Prema podjelama koje su citirane u ovome radu drugi sudio-

24 Početni su primjeri (bez zvjezdice) iz Hrvatskoga mrežnog korpusa (hrWaC).

25 This joke really killed the audience. 'Ova je šala ubila/uništila publiku.' (Arad 1998:14).

26 Tu nismo ubrojili genitive koji alterniraju s nominativom (Fali mi / Nedostaje mi ljubav/ljubavi.). 
nik radnje/stanja glagola zabavljati se i umiriti se smatrao bi se ciljem/predmetom emocije (Pesetsky 1996) te poticajem (Levin 1993) ili temom (RizziBelletti 1988). Brač (2018) u svojoj opsežnoj studiji o instrumentalu u hrvatskome jeziku argument neiskustvenika uz glagol zabavljati se i uz ostale psihološke glagole (oduševiti se, uzrujati se, ražalostiti se) smatra uzročnikom. Autorica ne razlikuje tematske uloge neiskustvenika uz psihološke glagole s objektnim i subjektnim iskustvenikom. Glagoli iznenaditi i razveseliti mogu drugoga sudionika psihološkoga stanja izraziti i dativom (37. a. i b.) i instrumentalom (38. a. i b.):

37. a. Iznenadila se odličnom muškom tekstu u ženskoj reviji.

b. Ivan se razveselio bratu.

38. a. Iznenadio se činjenicom da se meso pokvarilo.

b. Djeca su se razveselila sladoledom.

U primjerima 37. b. i 38. b. glagol razveseliti se nema isto značenje, sukladno opisu u Valencijskome rječniku psiholoških glagola u hrvatskome jeziku. U primjeru 37. b. značenje je glagola razveseliti se 'postati veseo', a u 38. b. 'učiniti sebe veselim' te se može pretpostaviti da bi i tematska uloga dativne i instrumentalne dopune $u z$ ta dva značenja glagola mogla biti nešto drukčija. Kod dativne dopune nedvojbeno je riječ o predmetu/cilju emocije, a instrumentalna dopuna uz glagola razveseliti se prima karakteristike $\mathrm{i}$ sredstva i uzročnika. Sladoled je i sredstvo i uzročnik postajanja veselim. Brač (2018) ne analizira glagol razveseliti se, ali uz glagol ražalostiti se, koji bismo mogli shvatiti antonimom glagola razveseliti se, kao što je već rečeno instrumentalnu dopunu smatra uzročnikom.

Kod glagola ražalostiti se i uzrujavati se drugi se sudionik radnje može izraziti prijedložnom skupinom ili instrumentalom:

39. Čovjek se vrlo lako može ražalostiti nad patnjama drugih.

40. Čovjek se vrlo lako može ražalostiti patnjama drugih.

U literaturi je čest predmet rasprava imaju li psihološki glagoli s objektnim iskustvenikom pasiv. Naime Belleti-Rizzi (1988) smatraju da su tzv. glagoli preoccupare (glagoli s objektnim iskustvenikom) neakuzativni, njihov je subjekt spojen kao unutarnji argument te pomaknut na subjektno mjesto, pa ne mogu imati pasiv. U hrvatskome dio glagola s objektnim iskustvenikom (iznenaditi, naviknuti, razveseliti, ražalostiti, umiriti, vrijeđati, uvrijediti, uzrujavati) može imati perifrastični pasiv, a dio ne može (brinuti, čuditi, radovati, veseliti, živcirati).

41. Tvoje me ponašanje iznenadilo / razveselilo / ražalostilo / umirilo / uvrijedilo. 
Matea Birtić, Siniša Runjaić: Sintaktičko-semantička podjela psiholoških glagola...

FILOLOGIJA 73(2019), 1-25

42. a. Ja sam iznenađen / razveseljen / ražalošćen / umiren / uvrijeđen tvojim ponašanjem.

b. Ja sam uvrijeđen na tebe / tvojim ponašanjem.

43. Ja sam *brinut $/{ }^{*}$ čuđen $/{ }^{*}$ radovan $/{ }^{*}$ veseljen / ${ }^{*}$ živciran / ?plašen ${ }^{27}$ tom viješću.

Iako je riječ o malenome broju glagola, vidljivo je da svršeni prefiksalni psihološki glagoli s objektnim iskustvenikom mogu tvoriti pasiv (uz iznimku nesvršenoga glagola vrijeđati), ${ }^{28}$ dok nesvršeni i neprefiksalni psihološki glagoli s objektnim iskustvenikom ne tvore pasiv. Takvo sintaktičko ponašanje psiholoških glagola s objektnim iskustvenikom moralo bi se promatrati unutar suodnosa pasiva i svršenoga, tj., nesvršenoga vida. Jedno od promišljanja toga suodnosa nudi Polančec (2015) koji kaže da je »Pasiv sigurno više povezan sa svršenim vidom time što se svršenim glagolima izražava stanje proizašlo iz prethodne radnje, što je česta funkcija pasiva (Polančec 2015:154). Međutim, gotovo je sigurno da na mogućnost pasivizacije tih glagola utječu i neki drugi činitelji, kao primjerice činjenica da psihološki glagoli s objektnim iskustvenikom prve skupine mogu, čini se, puno lakše dobiti agentivnu interpretaciju. ${ }^{29}$

27 U cijelome Hrvatskom mrežnom korpusu nalaze se dva primjera s pridjevom trpnim glagola plašiti, što ne čini ovu konstrukciju ovjerenom.

28 Perifrastični pasiv glagola vrijeđati potvrđen je mnogim korpusnim primjerima. Iako se u takvoj rečenici rijetko javlja instrumentalom izrečen uzročnik, ipak smo jedan takav primjer našli u Hrvatskome mrežnom korpusu: Jednako tako govori i u Međugorju, da je Bog previše vrijeđan tolikim zlima, tolikim grijesima...

29 Ako usporedimo glagole prve skupine (iznenaditi, razveseliti, ražalostiti, umiriti, uvrijediti, uzrujavati) možemo zamijetiti da, osim što se razlikuju od druge skupine (brinuti, čuditi, diviti...) prefiksalnošću i svršenošću, mogu biti rabljeni kao agentivni i neagentivni glagoli:

a. Tvoje me ponašanje iznenadilo.

b. Marko je Anu iznenadio buketom cvijeća.

$S$ druge strane, primjerice, glagol brinuti nema agentivne interpretacije:

c. Tvoje me ponašanje brine.

d. Marko brine Anu (? svojim ponašanjem).

Imenska skupina tvoje ponašanje uz glagol iznenaditi može se shvatiti kao uzročnik (prema Pesetsky 1996) ili efektor (prema Van Valin-LaPolla 1997) te nije svjesni pokretač radnje. Nasuprot tomu Marko se u primjeru b. svakako shvaća kao namjerni pokretač radnje (kupovanjem cvijeća), a na prisutnost agensa upućuje i prisutnost neke vrste instrumenta. Uz glagol brinuti, prema našoj intuiciji, oba se nominativna subjekta (u c. i d.) shvaćaju kao nenamjerni pokretači radnje, uzročnici ili efektori. Premda, kao što smo već naveli, jedan od recenzenata ovoga rada smatra da i glagol plašiti može imati namjernu interpretaciju. Ta razlika među glagolima ovih dviju skupina svakako utječe na mogućnost pasivizacije, samo je u ovome trenutku teško objasniti kako. Dvostruka interpretacija glagola iznenaditi svakako se može povezati s već spominjanom 
Mogućnost pasivizacije dijela objekata psiholoških glagola s objektnim iskustvenikom pokazuje da je kod tih glagola riječ o strukturnome, a ne o inherentnome ${ }^{30}$ akuzativu. ${ }^{31}$ Zanimljivo je primijetiti da se u primjeru 42. b. neživi uzročnik uz pasiv glagola uvrijediti može izreći, kao što je i uobičajeno, instrumentalom, ali i prijedložnom skupinom kad je riječ o živome uzročniku koja se inače javlja uz povratnu inačicu ovoga glagola.

Možemo zaključiti da je kod dijela psiholoških glagola s objektnim iskustvenikom pasivizacija moguća: objekt agentivne rečenice postaje subjektom pasivne, a uzročnik agentivne izriče se najčešće instrumentalom ili prijedložnom skupinom.

Sljedeća su podskupina glagoli kod kojih se iskustvenik izriče nominativnom dopunom i u prijelaznoj i povratnoj inačici:

\section{Osjećam tugu.}

45. Osjećam se tužno.

U obrađivanome su rječniku takva samo tri glagola: osjetiti/osjećati i poželjeti. ${ }^{32} \mathrm{Tu}$ svakako treba spomenuti glagole ćutjeti, zaželjeti (se) i poželjeti (se) koji bi također pripadali ovoj skupini glagola da su obrađeni u Valencijskome rječniku psiholoških glagola u hrvatskome jeziku. ${ }^{33}$

Podskupina su te skupine i glagoli koji mogu biti prijelazni i povratni, ali čija povratna inačica ima samo uzajamnopovratno značenje. U Valencijskome rječniku psiholoških glagola u hrvatskome jeziku to su samo glagoli voljeti i mrziti:

46. Volim djevojku.

47. Susjedi se vole.

tvrdnjom o dvostrukoj interpretaciji nekih glagola: agentivnoj i neagentivnoj (Van Valin-LaPolla 1997:119). Različite semantičke interpretacije ovih glagola treba povezati i s njihovom pripadnošću različitim podjelama glagola prema tipu situacije koju opisuju. Dok se psihološki glagoli s nominativnim iskustvenikom obično smatraju stanjima, za glagole s objektnim iskustvenikom nije jasno kojoj skupini pripadaju. Obično se tvrdi da mogu imati tri interpretacije: agentivnu, događajnu i stativnu, te mogu biti telični i atelični, a u hrvatskome još dodatno i svršeni i nesvršeni. Neki ih autori karakteriziraju kao atelične uzročne, a neki kao telične promjene stanja (Rozwadowska 2003).

30 Više o razlici strukturnih i inherentnih padeža vidi u Mihaljević (2010).

31 Belletti-Rizzi (1988) tvrde da je kod prijelaznih glagola sa subjektnim iskustvenikom (Marija obožava sladoled.) riječ o strukturnome akuzativu (i nominativu), i riječ je o prototipnim prijelaznim konstrukcijama. Kod prijelaznih psiholoških glagola s objektnim iskustvenikom (Izlet me veseli.) akuzativ (me) inherentan je padež. Ako je riječ o inherentnome padežu, ne bi trebala biti moguća pasivizacija (s izvornim objektom na subjektnome mjestu s nominativom).

32 Glagol poželjeti zapravo ima odgovarajući povratni glagol, ali je on samo rubno u uporabi (Poželio sam se kruha.).

33 To nam je također sugerirao jedan od recenzenata ovoga rada. 


\section{3. d. Prijelazni, neprijelazni i povratni glagoli}

Kao četvrtu podskupinu skupine prijelaznih glagola izdvojili smo glagole koji mogu biti neprijelazni, prijelazni i povratni iako bi se oni mogli svrstati u svaku od nabrojenih skupina (i u povratne i u neprijelazne). U obrađivanome rječniku takvim glagolima pripada samo glagol žaliti:

48. On žali za tobom još i danas.

49. Ja iskreno žalim cijeli taj narod.

50. Pacijent se žali na bolove.

Treba primijetiti da glagol žaliti u sve tri inačice ima drukčije značenje, iako za sva tri značenja možemo reći da su psihološka. Kad je glagol popraćen prijedložnom skupinom s prijedlogom za (48.), najčešće znači 'osjećati žalost za onim koga/čega nema', ako je popraćen objektom u akuzativu (49), znači ‘osjećati sućut prema komu, dijeliti žalost s kime', dok u povratnome obliku (50) znači 'iskazivati neraspoloženje ili nezadovoljstvo.'

\section{Zaključak}

Ovaj je rad pokazao da se u hrvatskome jeziku, kao i u mnogim drugim svjetskim jezicima, iskustvenik može ostvariti na tri načina (nominativnom, akuzativnom ili dativnom imenskom skupinom). Prema svojoj funkciji iskustvenik je subjekt, objekt ili neizravni objekt u dativu (koji se u našim gramatikama naziva i logičkim subjektom), stoga govorimo o psihološkim glagolima sa subjektnim, objektnim i dativnim iskustvenikom. Argument psihološkoga glagola koji nije iskustvenik autori nazivaju različito (tema, uzročnik, poticaj). Pojedini autori (Belletti-Rizzi 1988; Levin 1993; Brač 2018 (za instrumentale)) smatraju da oba argumenta svih tipova psiholoških glagola imaju iste tematske uloge (iskustvenik - tema/poticaj/uzročnik), dok drugi (Pesetsky 1996) različito određuju neiskustvenika uz glagole sa subjektnim iskustvenikom (predmet/cilj emocije) i neiskustvenika uz glagola s objektnim iskustvenikom (uzročnik).

Podijelivši glagole prema svojstvu prijelaznosti na čiste (prijelazni, neprijelazni i povratni) i miješane tipove (prijelazni i neprijelazni, povratni i prijelazni, itd.) te prema tome koji argument izriče iskustvenika (subjekt, izravni ili neizravni dativni objekt) izdvojili smo četiri osnovne vrste glagola (neprijelazni, povratni, prijelazni glagoli i glagoli koji mogu biti prijelazni, povratni i neprijelazni) i jedanaest podvrsta koje smo dobili kombinacijom dvaju parametara (prijelaznost i sintaktičko izricanje iskustvenika). Stoga se psihološki glagoli u hrvatskome jeziku dijele na: 1 . samo neprijelazne s nominativnim iskustvenikom, 2. samo neprijelazne s dativnim 
iskustvenikom, 3. samo povratne s nominativnim iskustvenikom, 4 . samo povratne s dativnim iskustvenikom, 5. povratne i neprijelazne, 6. samo prijelazne, 7. prijelazne i neprijelazne, 8. prijelazne s objektnim iskustvenikom i povratne, 9. prijelazne s nominativnim iskustvenikom i povratne, 10. prijelazne i uzajamnopovratne i 11. prijelazne, neprijelazne i povratne.

Manje od polovice glagola (27) u Valencijskome rječniku psiholoških glagola $u$ hrvatskome jeziku pripada samo jednomu tipu prema kategoriji prijelaznosti (sedam ih je samo neprijelazno, devet je samo prijelazno, dok ih je jedanaest samo povratno), dok ostalih trideset glagola pokazuju sintaktičku varijantnost s obzirom na svojstvo prijelaznosti. Najveći broj pripada tipu glagola koji imaju povratnu i prijelaznu inačicu s objektnim iskustvenikom (šesnaest glagola), a zatim slijede reflexiva tantum (glagoli koji se mogu pojaviti samo s česticom se) kojih ima jedanaest. Treba napomenuti da je pedeset i sedam psiholoških glagola dio abecedarija glagola (900 glagola) za planirani Valencijski rječnik glagola u hrvatskome jeziku, za koji su leksemi birani prema načelu čestotnosti i funkcionalnosti. ${ }^{34}$

Ovo je istraživanje također pokazalo da temeljno psihološki glagoli s objektnim iskustvenikom imaju gotovo uvijek i povratnu inačicu. Utvrđeno je da samo oni glagoli s objektnim iskustvenikom koji u prenesenome smislu mogu zadobiti psihološko značenje nemaju odgovarajuću psihološku povratnu inačicu (Hvata me jeza. *Hvatam se jezom.). Također smo utvrdili da samo dio psiholoških glagola s objektnim iskustvenikom može imati perifrastični pasiv. To su ponajprije svršeni i prefiksalni glagoli kojima je u određenim kontekstima dostupna agentivna interpretacija, dok nesvršeni, neprefiksalni glagoli bez mogućnosti agentivne interpretacije ne mogu biti pasivizirani (uz iznimku glagola vrijeđati koji je nesvršen i neprefiksalan, ali može biti agentivno interpretiran). Mogućnost pasivizacije upućuje na to da je kod dijela psiholoških glagola s objektnim iskustvenikom akuzativ strukturni padež. Tijekom pasivizacije objekt postaje subjekt pasivne rečenice, kao što je i uobičajeno, dok nominativni argument izvorne rečenice u pasivnoj postaje instrumental ili oblikom odgovara prijedložnoj skupini koja se javlja uz povratnu inačicu istoga glagola. Zanimljivo je da drugi argument pasivnoga glagola može oblikom korelirati s drugim argumentom povratnoga glagola (riječ je o neiskustveniku), što govori u prilog derivacijskoj povezanosti dviju inačica glagola. Skupina psiholoških glagola s objektnim iskustvenikom iznimno je zanimljiva te nedovoljno istražena i u hrvatskome pa bi joj trebalo posvetiti više pozornosti.

34 Za sada možemo nagađati da se nijedna nova sintaktičko-semantička vrsta ne bi pojavila da istražimo i sve psihološke glagole u hrvatskome jeziku, premda je teško reći bi li njihova rasprostranjenost bila drukčija. 
Matea Birtić, Siniša Runjaić: Sintaktičko-semantička podjela psiholoških glagola...

FILOLOGIJA 73(2019), 1-25

Na kraju rada donesen je popis psiholoških glagola s dativnim (18) i objektnim iskustvenikom (84) koje su do sada prikupili autori ovoga rada.

Psihološki glagoli s dativnim iskustvenikom u hrvatskome jeziku:

dojaditi, dodijati, dosaditi, dosadivati, dozlogrditi, goditi, dopadati se, dopasti se, gnušati se, militi se, nedostajati, omiliti se, prisjesti, sažaliti se, smiliti se, svidjeti se, sviđati se, trebati. ${ }^{35}$

Psihološki glagoli s akuzativnim iskustvenikom $\mathrm{u}$ hrvatskome jeziku:

brinuti, čuditi, ganuti, gnjaviti, hrabriti, izbezumiti, izbezumljivati, iznenaditi, iznenađivati, iznervirati, iznevjeriti, ljutiti, mučiti, nadahnuti, nadahnjivati, naljutiti, namučiti, nervirati, obradovati, obuzeti, obuzimati, očarati, očaravati, oduševiti, oduševljavati, oneraspoložiti, oneraspoloživati, oplemeniti, oplemenjivati, oraspoložiti, osupnuti, ožalostiti, patiti, plašiti, poludjeti, poplašiti, prestrašiti, prisjećati, radovati, raspoložiti, rastužiti, rastuživati, razočarati, razočaravati, razveseliti, ražalostiti, sjećati, smesti, sramotiti, srditi, strašiti, snužditi, umiriti, uplašiti, usrećiti, usrećivati, utješiti, uvrijediti, uzbuditi, uzbudivati, uznemiriti, uznemirivati, uzrujati, uzrujavati, užasavati, veseliti, vrijeđati, zabavljati, zabrinuti, zabrinjavati, zadivljavati/zadivljivati, začuditi, začuđivati, zadiviti, zanositi, zaprepastiti, zaprepašćivati/zaprepaštavati, zastrašiti, zastrašivati, zbuniti, zbunjivati, žaliti, žalostiti, živcirati. ${ }^{36}$

35 Ovdje su popisani samo glagoli koji su u svojemu temeljnom značenju psihološki, a tu svakako pripadaju i oni koji su u prvome redu glagoli fizičkoga stanja, pa tek preneseno i psihološkoga stanja: gaditi se, ogaditi se, smučiti se, zgaditi se. Glagoli zamjeriti se i smetati u svojoj neagentivnoj uporabi također su glagoli psihološkoga stanja s dativnim iskustvenikom (Njegovo ponašanje mi smeta / zamjerilo mi se.).

36 U gornjemu su popisu navedeni glagoli koji su u svojemu temeljnom značenju psihološki. Ovoj skupini (psihološki glagoli s objektnim iskustvenikom) pripadaju i glagoli boljeti, dirati, dražiti, iscrpiti, iscrpljivati, kopkati, gnjaviti, gristi, mučiti, onesposobiti, onesposobljavati, opametiti i potresti koji u temeljnome značenju nisu psihološki. Kod nekih je glagola također nejasno treba li ih smatrati primarno psihološkim ili ne, to jest koje im je temeljno značenje, npr. glagol uzbuditi. 
Matea Birtić, Siniša Runjaić: Sintaktičko-semantička podjela psiholoških glagola...

FILOLOGIJA 73(2019), 1-25

\section{Literatura}

Alexiadou, Artemis; Gianina Iordăchioaia. 2014. The psych causative alternation. https://www.academia.edu/11844275/The_Psych_Causative_ Alternation (pristupljeno 15. 2. 2019.)

Arad, Maya. 1998. Psych-notes. UCL Working Papers in Linguistics, 10, 1-22.

Baker, Mark C. 1988. Incorporation - A Theory of Grammatical Function Changing. Chicago - London: The university of Chicago Press.

Barić, Eugenija i dr. ${ }^{2} 1997$. Hrvatska gramatika. Zagreb: Školska knjiga.

Belaj, Branimir. 2004. Pasiona rečenica. Osijek: Filozofski fakultet Sveučilišta Josipa Jurja Strossmayera.

Belaj, Branimir; Goran Tanacković Faletar. 2011. Cognitive foundation of emotion verbs complementation in Croatian. Suvremena lingvistika, 37/72, 153-169.

Belaj, Branimir; Goran Tanacković Faletar. 2017. Kognitivna gramatika hrvatskog jezika. Knjiga druga. Sintaksa jednostavne rečenice. Zagreb: Disput.

Belletti, Adriana; Luigi Rizzi. 1988. Psych-Verbs and $\theta$-Theory. Natural Language and Linguistic Theory, 6/3, 291-352.

Birtić, Matea. 2008. Unutarnja struktura odglagolskih imenica u hrvatskome jeziku. Zagreb: Institut za hrvatski jezik i jezikoslovlje.

Birtić, Matea i dr. 2018. Valencijski rječnik psiholoških glagola u hrvatskome je$z i k u$. Zagreb: Institut za hrvatski jezik i jezikoslovlje.

Brač, Ivana. 2018. Instrumental u hrvatskom jeziku. Zagreb: Institut za hrvatski jezik i jezikoslovlje.

Brač, Ivana; Ivana Matas Ivanković. 2016. Психологические глаголы в хорватском и русском языках. Ur. Skwarska, Karolína; Elżbieta Kaczmarska. Research of Verbal Valency in Slavic Languages in the Past and Present. Výzkum slovesné valence ve slovanských zemích včera a dnes. Praha: Slovanský ústav AV ČR, v.v.i., 351-369.

Croft, William. 1993. Case Marking and Semantics of Mental Verbs. Ur. Pusejeovsky, James. Semantics and Lexicon. Norwell, MA.: Kluwer Academic Publishers, 55-72.

Grafmiller, Jason. 2013. The semantics of Syntactic Choice: An Analysis of English Emotion Verbs. A dissertation. Stanford: Stanford University.

Grimshaw, Jane. 1990. Argument Structure. Cambridge, MA.: The MIT Press.

Katičić, Radoslav. ${ }^{32002 . ~ S i n t a k s a ~ h r v a t s k o g a ~ k n j i z ̌ e v n o g ~ j e z i k a . ~ Z a g r e b: ~ N a-~}$ kladni zavod Globus - Hrvatska akademija znanosti i umjetnosti.

Kuna, Branko. 2012. Predikatna i vanjska posvojnost u hrvatskome jeziku. Filozofski fakultet J. J. Strossmayera u Osijeku. 
Matea Birtić, Siniša Runjaić: Sintaktičko-semantička podjela psiholoških glagola...

FILOLOGIJA 73(2019), 1-25

Landau, Idan. 2010. The Locative Syntax of Experiencers. Cambridge, MA.: MIT Press.

Levin, Beth 1993. English Verb Classes and Alternations: A Preliminary Investigation. Chicago - London: University of Chicago Press.

Matovac, Darko; Goran Tanacković Faletar. 2010. Semantička uloga efektora kao determinatora dativnih dopuna u neraščlanjenim jednostavnim rečenicama. Ur. Birtić, Matea; Dunja Brozović Rončević. Sintaksa padeža. Zbornik radova znanstvenog skupa s međunarodnim sudjelovanjem Drugi hrvatski sintaktički dani. Zagreb: Institut za hrvatski jezik i jezikoslovlje, 163-178.

Mihaljević, Milan. 2010. Strukturni i nestrukturni padeži u hrvatskom jeziku. Ur. Birtić, Matea; Dunja Brozović Rončević. Sintaksa padeža. Zbornik radova znanstvenog skupa s međunarodnim sudjelovanjem Drugi hrvatski sintaktički dani. Zagreb: Institut za hrvatski jezik i jezikoslovlje, 179_ 192.

Oraić Rabušić, Ivana. 2016. Rečenice kao dopune uz psihološke glagole. Fluminensia: časopis za filološka istraživanja, 28/2, 71-86.

Palić, Ismail. 2010. Dativ u bosanskome jeziku. Sarajevo: Naučna biblioteka "Slovo".

Pesetsky, David. 1996. Zero Syntax: Experiencers and Cascades. Cambridge, MA.: MIT Press.

Polančec, Jurica. 2015. Uporaba participa pasivnog u nesvršenome vidu u hrvatskome jeziku. Fluminensia: časopis za filološka istraživanja, 27/2, 141-160.

Raguž, Dragutin. 1997. Praktična hrvatska gramatika. Zagreb: Medicinska naklada.

Rozwadowska, Bożena. 2003. Initial Boundary and Telicity in the Semantics of Perfectivity. Eds. Kosta, Peter, Joanna Błaszczak, Jens Frasek, Ljudmila Geist, Marzena Żygis. Investigations into Formal Slavic Linguistics. Berlin: Peter Lang, 859-872.

Rozwadowska, Bożena. 2017. Psychological Verbs and Psychological Adjectives. https://pracownik.kul.pl/files/10932/public/syncom_psych_verbs_ revised.pdf?1461263014580. (pristupljeno 15. 1. 2019.)

Samardžija, Marko. 1986. Valentnost glagola u suvremenom hrvatskom književnom jeziku. Doktorska disertacija. Zagreb: Filozofski fakultet Sveučilišta u Zagrebu.

Schäfer, Florian. 2009. The causative alternation. Language and Linguistics Compass, 3/2, 641-681.

Silić, Josip; Ivo Pranjković. 2005. Gramatika hrvatskoga jezika. Zagreb: Školska knjiga. 
Matea Birtić, Siniša Runjaić: Sintaktičko-semantička podjela psiholoških glagola...

FILOLOGIJA 73(2019), 1-25

Šaravanja, Lidija. 2011. Argumentna struktura psiholoških glagola u hrvatskom jeziku. Suvremena lingvistika, 37, 241-257.

Težak, Stjepko; Stjepan Babić. ${ }^{15} 2005$. Gramatika hrvatskoga jezika. Zagreb: Školska knjiga.

Van Valin, Robert D.; Randy J. LaPolla. 1997. Syntax: Structure, meaning and function. Cambridge - New York - Melbourne: Cambridge University Press.

\title{
The syntacticosemantic classification of psychological verbs in the Croatian language
}

\begin{abstract}
The paper proposes a syntacticosemantic classification of Croatian psychological verbs based on 57 verbs contained in Valencijski rječnik psiholoških glagola $u$ hrvatskome jeziku (Valency dictionary of psychological verbs in the Croatian language), i. e. in its online version $e$-Glava. The verbs are distributed into three major groups based on their transitivity. Further subgroups are established on the linking of experiencer with a certain syntactic position, i. e. with the function of a subject, direct object and indirect object (which syntactic function realizes a thematic role of experiencer). The morphological form of experiencers and non-experiencer arguments are analyzed in detail for each subgroup of psychological verbs. The most numerous subgroup among 57 psychological verbs is the group, which has both reflexive and transitive variant. Their transitive variant belongs to Object Experiencer Verbs (brinuti (se) 'worry (self)', čuditi (se) 'wonder (self)', ljutiti (se) 'anger (self)'). The syntactic behavior of these verbs is also analyzed in detail in this paper.

Although the classification of psychological verbs suggested here is established on the basis of verbs extracted from Valencijski rječnik psiholoških glagola $u$ hrvatskome jeziku (Valency dictionary of psychological verbs in the Croatian language) and the verbs processed here are mostly from that dictionary, at the end of the paper there is a comprehensive list of all verbs with accusative or dative experiencer in the Croatian language which the authors collected so far.

Ključne riječi: psihološki glagoli, hrvatski jezik, glagoli sa subjektnim iskustvenikom, glagoli s objektnim iskustvenikom, glagoli s dativnim iskustvenikom

Keywords: psychological verbs, the Croatian language, Subject Experiencer Verbs, Object Experiencer Verbs, Dative Experiencer Verbs
\end{abstract}


